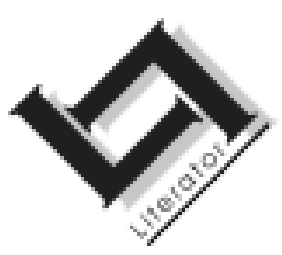

\title{
Konflik, representasie, interpretasie - die waarheid gelieg
}

\author{
Rensia Robinson \\ Departement Afrikaans en Nederlands \\ Universiteit van Stellenbosch \\ STELLENBOSCH \\ E-pos: philren@freemail.absa.co.za
}

\section{Abstract}

Conflict, representation, interpretation - the truth lied

The poetic concept "taalskadeloosstelling" (disempowerment of speech) in a poem by T.T. Cloete can be related to a poetic procédè in another of his poems, namely "Foto Boerevegters" from the volume Driepas (1989: 111). In this poem the relativity of conflict is a main theme. The telescoping of contexts and perspectives reveals more fundamental conflicts than the superficial theme of a specified historical conflict. A framed representation (a photograph) of a political event represents a retrogressive perspective that presupposes a more comprehensive context. Such a double perspective degrades and relativizes the representation to the level of reconstructed jigsaw pictures on paper.

Discrepancies between appearance and intention, or surface and depth structures are unmasked at a linguistic level. In contrast with the lies of representation, the discourse of the poem exceeds its own constraints. This activates the establishment of relationships that render comment from an enlarged perspective. The framework of a local historical context is thus broken through and momentarily truth and lie are juxtaposed.

\section{Inleiding}

Na my wete word T.T. Cloete nie in die Suid-Afrikaanse literêre konteks beskou as struggle-digter of getipeer as sosiaal-polities betrokke digter nie. In 'n gedig soos "Ballade van die digter" (1986:66), wat as 'n ars poetica gelees kan word, is daar sprake van 'n digterlike perspektief wat oënskynlik klop hiermee. Veelseggende reëls uit hierdie gedig is byvoorbeeld die volgende: "In tye van groot terreur ...//sit (die digter) sy pen met sy lippe en liefkoos" en in dieselfde gedig lui dit ook: "Die digter gaan onbarmhartig onverstoord / te midde van die algemene verderf / met sy taalskadeloosstelling voort" (my kursivering - RR). 
Op die oog af gaan dit hier om 'n begrip wat ontpolemiseer - dus 'n standpuntinname teen 'n strydvaardige digterlike styl. Dit is so 'n tegniek van "taalskadeloosstelling", wat na my mening tiperend is van 'n onderskeibare digterlike procédé, waaroor ek groter helderheid wil probeer kry in hierdie artikel. As heuristiese model hiervoor maak ek gebruik van 'n gedig van T.T. Cloete met die Suid-Afrikaanse AngloBoereoorlog as 'n onderliggende tema (die teks van die gedig word afgedruk by punt 8 van dié artikel). Die titel daarvan is "Foto Boerevegters" in die bundel Driepas (1989:111).

Oorloë is keerpunte in die geskiedenis. Dit polemiseer grense en denkpatrone en open alternatiewe diskoerse. Teen so 'n tematiese agtergrond word die ambivalente moontlikhede van die Cloete-konsep, "taalskadeloosstelling", in hierdie artikel ontgin.

\section{Outeurskode}

Soos reeds herhaaldelik aangetoon in verskillende studies in verband met aspekte van Cloete se oeuvre, is sy eie teoretiese bydraes betekenisvolle sleutels in die verstaansproses van sy poësie. Aangesien intensionaliteit te maak het met, soos De Beaugrande en Dressler (1981:116) dit stel, "the ways in which text producers utilize texts to pursue and fulfil their intentions", is dit nie enkelvoudig af te lei nie. Dit is verweef in 'n teks en in 'n oeuvre. In die poësie hang dit in 'n groot mate saam met die ewe ontwykende verskynsel van implikasie. Snyman (1983:13) evalueer laasgenoemde verskynsel nietemin as "miskien die magtigste wapen ... om die woord tot 'toorklip' te omskep". Kunstenaars maak eksplisiete en implisiete uitsprake oor die onthullende/verhullende/ verkullende aard van die kunswerk. Deur rekenskap te gee van 'n proses van betekenistoekenning aan 'n gekose gedig kom die interaksie tussen outeursintensie en leserreaksie ter sprake.

Met die oog op die mees effektiewe agterhaling van outeursintensie word in hierdie ondersoek gebruik gemaak van 'n aantal leidrade uit die Cloete-oeuvre. In een van sy artikels, na aanleiding van Opperman se opstel "Kuns is boos", kom hy tot dié gevolgtrekking: "Die spanning in die vermeende spanninglose werk kan selfs so verborge wees dat dit tussen die vers- en sinsbou of tussen die metrum en ritme kan lê, met ander woorde, hierdie dinge kan ook 'teenbeelde' van mekaar wees" (Cloete, 1974:42). Sulke konflik-tipes noem hy (Cloete, 1974:34) "korrektiewe moontlikhede" en hy wys daarop dat "die bose nie net as korrektief (kan) optree nie, maar sélf ook 'n korrektief nodig het" (Cloete, 1974:33). Die korrektief is "n wesenlik dramatiese gegewe" en in die drama (en die poësie) staan dit "in die nouste verband met "die aard van die konflik". Met hierdie uitspraak in gedagte word gekyk na die oënskynlik 
ongekompliseerde gedig "Foto Boerevegters". Slegs die twee slotreëls van dié gedig vestig die aandag op 'n disjunktiewe skakeling met die voorafgaande versreëls wat 'n moontlike spanningselement (argumentatiewe kode) verraai. Ten slotte word oorweeg in watter mate die digter se begrip "taalskadeloosstelling" hierop van toepassing is.

Veelseggend kom die gedig "Foto Boerevegters" voor in die bundel Driepas in 'n onder-afdeling getitel "Duvelrieë", wat juis so 'n teenbeeld impliseer soos waarna Cloete verwys in die genoemde opstel. Die bundel Driepas vier onder andere die ritme (die driepas musikaal verstaan) van die skepping. Die driepas is onder andere embleem van die Goddelike as kreatief-aktiewe Drie-eenheid.

'n Teenbeeld van die Goddelike driepas is die tweepas (marsmaat), 'n simbool van konflik (Cirlot, 1982:232). Die tweepas is ook 'n simbool van verbygaande tyd, en dus betekenisvol in "Foto Boerevegters", waarin tydsverloop 'n sleutelrol speel. In al die gedigte van die afdeling "Duvelrieë" is konflik, die tweepas, 'n tema. Sulke konflik word egter ook telkens as gevolg van die verloop van tyd ontmasker en gerelativeer. In Cloete se gedig "Inter nos" (1989:113) lui dit byvoorbeeld: "om vir die nageslag te sterf is alte laf". Die interaksie tussen die voorbeeldgedig en die res van die gedigte in die afdeling "Duvelrieë" lewer waardevolle insigte op vir die leser.

Die begrip duvelrieë kom van die Nederlandse duvelryen, "scenes met duivels", uit die Middeleeuse mirakelspele (Knuvelder I, 1970:383). Dit is dus tipiese dramatiese gebeure, soos dié waarna Cloete verwys het in verband met die funksionering van teenbeelde. Die soort demoniese figure wat optree in Middeleeuse misteriespele speel die rol van "domme, bedrogen duiwels in komische rolle" volgens die Grote Winkler Prins (1980:632). In Mariken van Nieumeghen (Koopmans, 1917:27) is die hoofkarakter se tante (Moeye) so 'n figuur. Na aanleiding van haar optrede word gesê: "Paertiscap verdoempt menighe siele". Sulke karakters figureer dus spesifiek in konfliksituasies (vgl. Cloete se gedig "Tiener toneelliefhebber", 1982:20). Die Engelse begrip devilries, wat onder andere betekenisskakerings soos boosheid, wreedheid, roekeloosheid en duiwelskuns insluit (Ilson, 1984), is vergelykbaar hiermee. Hierdie inligting is betekenisvolle sleutels waarmee na die gedig gegaan kan word. Konflik impliseer partydigheid wat weer lei tot opponerende gesigspunte.

Die gedig "Ballade van die digter" (Cloete, 1986:66), waarin die begrip "taalskadeloosstelling" voorkom, word benut as agtergrondteks aangesien daarin ook leidrade voorkom in verband met Cloete se tipering van die sosio-historiese funksie van die digter en sy maaksel, die poësie. Dit 
is ' $n$ aspek wat vanselfsprekend relevant is vir 'n gedig oor ' $n$ bepaalde oorlog. "Ballade van die digter" kom voor in die bundel Idiolek. Die idiolek verwys na 'n indiwidu se eiesoortige stem (styl), wat 'n aanduiding is dat dit 'n bydrae kan lewer tot die samestelling van 'n outeurskode.

\section{Vooropstelling van diskoers}

Een van die opvallendste aspekte van die gedig onder bespreking is die vooropstelling van bepaalde gedigsegmente (vgl. "foregrounding" in Van Peer, 1986). Aan die hand van 'n historiese foto of dokumentêre getuienis ("argiefmateriaal", vgl. Hutcheon, 1991:36) word 'n groep oorlogmakers onder die vergrootglas geplaas. Aangesien dit 'n agternaperspektief is op gebeure van ongeveer honderd jaar gelede, kom uitgediende sosiale kodes ter sprake. 'n Spanningsverhouding ontstaan tussen representasie en interpretasie. Vanselfsprekend betrek dit die digotomie waarheid en leuen. Hierdie verskillende elemente ontplooi op strukturele wyse in die gedig. Daar is sprake van die jukstaponering van woord- en visuele teks, historiese en kulturele kontekste en uiteindelik 'n spesifieke (kultuurgebonde) diskoers en 'n groter diskoers. Die oogmerk van die ondersoek is om hierdie verbande na te gaan. Diskoers word deur Hutcheon (1991:4) getipeer as "the system of relations between parties engaged in communicative activity".

Vooropstelling van die diskoers-modus bring vanselfsprekend perspektiefwisseling ter sprake. Uspensky (1983:1) wys daarop dat alle kunsvorme wat verband hou met semantiek, dit wil sê met die representasie van 'n deel van die werklikheid soos verteenwoordig deur 'n denotatum, die kwessie van perspektief (point of view) sentraal plaas. Hy (Uspensky, 1983:8) betoog verder in dié verband:

When we speak of the system of ideas that shape the work, we are speaking about the deep compositional structure, as opposed to the surface compositional structure which may be traced on the psychological, spatio-temporal, or phraseological levels.

By die diskoers-modus speel die posisies van spreker en hoorder in die taalgebruik 'n aansienlike rol (Van Gorp, 1986:102).

\section{Diskoersanalise}

Die markante slotreëls van die gedig ondergrawe uit die staanspoor 'n historiese foto as lewensgetroue dokument. ' $n$ Foto van vegters is 'n ironiese teenbeeld van vegters in lewende lywe. Daar word gesuggereer dat die Boerevegters van die foto by implikasie gestagneer het tot papierpoppe omdat hulle vroeëre strydvaardigheid "op papier" alle 
betekenis verloor het. Op grond van hulle ambivalente voorkoms word hulle in die gedig geïroniseer as bluffers. Dit blyk dat reeds in die titel van die gedig diskursiewe moontlikhede geleë is wat deur die digterlike diskoers na die oppervlak gebring word.

Uit hierdie problematisering van die titel spruit bykomende diskoerse voort. Hier is sprake van herhaling, van ellipse, van substitusie, van ordening en hiërargisering van verssegmente wat verbande suggereer ter wille van diskursiewe oogmerke. Lakoff (1980:93) beweer byvoorbeeld: "In a good argument ... each element of form is used to express content" en (1980:98) "the network of connections (in an argument) has an overall structure". Terwyl Easthope (1983:21) die omskrywing van poësie enersyds handhaaf as "a distinct and concrete practice with its own independence, conforming to its own laws and effects", wys hy andersyds daarop dat "poetry is always a poetic discourse, part of a social formation defined historically".

Foniese kettings in die gedig vestig die aandag op moontlikhede van betekenisontplooiing. Dit blyk dat konsepte wat spanningsmomente en ambivalensie vooropstel, klankmatig verbind word. Deur alliterasie word Foto, vegters, veer, verkyker, vryers en vilthoed verbind. In hierdie reeks val semantiese kontraswerking op, byvoorbeeld tussen "foto" (wat gefokus is) en "verkyker" (afstandelik sien), terwyl daar 'n anomalie is tussen "vegters" (oorlogmakers) wat meer lyk na "vryers" (liefdemakers). Hiernaas is "'n veer in 'n vilthoed" pretensieuse oorlogsdrag.

Benewens die genoemde verbandlegging, roep die reeks klankmatig die weggelate teenpool van vegters op, naamlik (gevegs)vyand. Raadpleeg die leser historiese bronne, blyk dit dat verwysings na die fisiese voorkoms van dié Boerevegters op die foto fokus op aspekte wat kontrasteer met die afwesige, maar veronderstelde vyand - die Britse vegters. Laasgenoemde vegters was wel uitgerus met oorlogsdrag - militêre uniforms en swaar artillerie. Hierteenoor was die Boerevegters oorwegend geklee in burgerlike drag. Hulle beweeglikheid te perd en hulle ondervinding as jagters was een van hulle belangrikste bates. Teenstellend met die Boerevegters was die Britse vegters oor die algemeen minder bebaard (vgl. Pretorius, 1998).

'n Ander voor die hand liggende maar weggelate konsep wat klankmatig ter sprake kom, is vroue, sleutelrolspelers in die Anglo-Boereoorlog, maar ook semanties verwant aan vryers. Die feit dat hierdie perspektiewe in die foto ontbreek, bring terugskouend, ideologiese uitgangspunte ter sprake. In watter mate is die foto 'n selektiewe verheerliking van sommige oorlogshelde? Andersyds is die keuse van verteenwoordigers merkers van sosio-politieke kodes. 
Die /f/-foneem word verteenwoordig in elke segment van die gedig (twee maal in die titel en in elk van die vier strofes). Die tweede foniese ketting eggo die [u]-klank uit die sleutelbegrip "Boere". Dit volg 'n alternatiewe patroon. Begrippe met hierdie foneem is gekonsentreer in die eerste strofe, kom glad nie voor in die twee middelste strofes nie maar word gebruik as rymklank in die eerste en laaste strofes van die gedig. Semanties stel dit die verbinding van "hoede" en "woede" voorop in die eerste strofe en "(vilt)hoed" en "(helde)moed" in die laaste strofe. Emotiewe begrippe ("woede", "heldemoed", "Boere-oë") word gekonsentreer binne hierdie klankreeks. Hierdie begrippe kom ook slegs voor in die eerste inventaris. Deurdat sowel die [f]-klank as die [u]-klank verteenwoordig is in "vilthoed", skakel dit die twee klankreekse met mekaar waardeur dieselfde komplementêre verhouding geskep word as deur die komponente van die konsep "Boerevegters". Deur die skakeling van "vilthoed" met "vegters" en "verkyker" markeer dit 'n simboliese interpretasie van "hoed" as 'n teken van gesag, in dié geval militêre gesag. Cirlot (1982:140) verwys byvoorbeeld na Jung se siening van die hoed as "crown' and summit of an individual". Na aanleiding daarvan word dié gevolgtrekking gemaak: "The choice of a hat - associated with a particular social order - denotes the desire to be admitted to that set or to partake of its inherent characteristics".

Aan die ander kant lei die skakeling met "paprand- en opslaanhoede" tot 'n vooropstelling van 'n alternatiewe implikasie van "vilthoed", naamlik dat dit eerder met futloosheid geassosieer kan word (in aansluiting by "dowwe Boere-ö̈"). Andersins kan dit geassosieer word met windmakerigheid, indien die "veer-in-die-hoed"-isotopie in aanmerking geneem word. In al die gevalle kom die ambivalensie van die manlike hoed ter sprake - die hoed is deel van die burgerlike drag, maar op die foto funksioneer dit as militêre drag met allerlei konnotasies vir die waarnemer. Hierdie begrippe sluit aan by die reeds genoemde emotiewe begrippe. In dié opsig word "vryers" uit die eersgenoemde foniese ketting semanties betrek. Die rympatrone ondersteun klankmatig semantiese verbande tussen kultuur-historiese en sosiale merkers. Die waarnemende liriese subjek stel deurgaans teenstrydighede in die voorkoms van die Boerevegters voorop. Patroonvorming en die funksie daarvan word deur Thorne (in Van Peer, 1988:281) soos volg omskryf: "Patterns' are the product of repeated occurrences of linguistic forms, each pattern realizing a theme".

\section{Die jukstaponering van representasies en interpretasies}

'n Sleuteldiskoers wat deur die invoering van 'n foto in die gedig op die voorgrond geplaas word, is dié van representasie en interpretasie. Die 
foto as verbeeldingskonstruk binne die konteks van die gedig suggereer 'n struktuur van herhaling waarvan die basis niks anders as representasie kan wees nie (vgl. Derrida, 1991:10). Dit is 'n voorstelling, in die sin van 'n plaasvervanging, van reële voorwerpe. Terselfdertyd funksioneer dit as 'n her-aanbieding of re-produksie van 'n aanvanklike voorstelling of posering (deur die figure). Volgens Derrida (1991:10) word die konsep "oorspronklik" in so 'n geval geneutraliseer as 'n vorm van "standvastige" representasie. Wat is die oorspronklike agter die foto (onder andere ook die intensie daarvan)? De Beaugrande (1980:72) waarsku: "it (is) hard to determine ... how much seemingly accurate recall is in fact a reproduction rather than a reconstruction". Vanselfsprekend bring dit die proses van interpretasie in gedrang. Deurdat representasie en interpretasie op verskillende maniere in die gedig geproblematiseer word, blyk dit dat voortgaande (historiese) prosesse van representasie en interpretasie bevraagteken word.

Hutcheon (1991:43) wys byvoorbeeld daarop dat fotografie postmodernisties gesien word as 'n vorm van diskoers. Deur die samevoeging van die visuele en die verbale, meen Hutcheon (1991:125), "the actual words, when read in relation to the picture, turn it against itself as in (a) double-meaning play". Sy (1991:130) verduidelik die verdere verloop van hierdie proses soos volg:

If photography is, as a visual medium, inherently paradoxical, it is also semiotically hybrid. In Peirce's terms, it is both indexical (its representation is based on some physical connection) and iconic (it is a representation of likeness) in its relation to the real. This complex hybrid nature is another reason why photography has become particularly important in a time of challenge to modes of representation ... [l]n Peirce's terminology, the addition of language is the addition of the symbolic to the indexical and the iconic.

Deur ' $n$ foto as diskursiewe element in die digterlike diskoers in te voer, word 'n dubbele waarnemingsproses gestimuleer. Dit dra daartoe by om die aandag te vestig op die transformasie van taaltekens. In plaas daarvan dat dié foto ' $n$ ikoon is van heldemoed, soos gesuggereer word in die voorlaaste versreël van die laaste strofe, word dit gedegradeer tot simbool van verganklikheid en verbrokkeling (vergelyk die frase: "dit ruik alles na lak en karton en papier"). Die gedig destabiliseer die aanname dat die geposeerde foto gelees moet word as 'n representasie van 'n outentieke historiese teks. Daar word eerder gesuggereer dat die ambivalensies en relativering van 'n postmodernistiese teks deel vorm van so 'n dokument. 
Aangesien dit blyk dat die gedig kommentaar lewer op die foto, word foto en gedig gejukstaponeer as vorme van representasie en interpretasie. Dit gee op sigself aanleiding tot 'n verwikkelde diskoers. 'n Foto het 'n komplekse sosiale funksie (vgl. Hodge, 1990:205). Dit funksioneer as ver-taling van die visuele, in dié geval 'n sekondêre bron. Die leser het nie die meesterkopie (die reële foto) voor oë nie, maar word gestuur deur die kommentaar in die gedig om die foto te visualiseer. Dit suggereer 'n proses van verbeeldingryke spieëlbeelding waaruit 'n leserinterpretasie gerekonstrueer moet word.

Die foto verteenwoordig 'n momentopname, 'n stolling uit die tyd, wat andersins deel uitmaak van verwikkelde prosesse. Dit skep 'n parallel met oorlog wat as tema dien en wat in isolasie gesien, ook slegs momentopnames van eindelose prosesse verteenwoordig. Die intensiteit waarmee die oorspronklike rolspelers so 'n lewensontwrigtende fase beleef het, reflekteer nie in hulle uiterlike voorkoms nie. Met 'n foto word 'n geïsoleerde aspek van so 'n oorlogsituasie omraam. Dit bring 'n ingeperkte waarneming mee en laat alternatiewe afleidings toe omdat dit buite konteks aangebied word. Interpretasie word onder andere gestuur deur die soort kennis wat oor die weggelate konteks beskikbaar is. Dit word herhaaldelik ingevul en tot lewe gebring deur die wyse waarop daarna gekyk word. Sulke perspektiewe vorm nie noodwendig deel van die representasie nie. Die soort diskrepansies tussen verlede en hede wat langs hierdie weg ontstaan, open meervoudige diskoerse ten opsigte van 'n spesifieke foto en 'n spesifieke oorlogsituasie. Botsende ideologiese uitgangspunte vorm die basis daarvan.

Teenoor die foto as statiese voorstelling, ontplooi die gedig as "n wordende structuur" (Stutterheim, 1963:84) wat meervoudige perspektiewe kan inkorporeer en reflekteer. Leserreaksie en liriese subjekkykerreaksie tree in wisselwerking met mekaar. Die vermenigvuldiging van perspektiewe lei tot wat De Beaugrande (1980:65) soos volg omskryf: "... [I]n an extensive and richly interconnected world, the declarative and procedural aspects begin to converge". Verbandlegging en betekenismoontlikhede in die gedig word, vanweë die vooropstelling van die onstandvastigheid van sosio-historiese uitgangspunte, nie deur enige lesing afgesluit nie.

Soos die fotograaf en sy objekte selektief te werk gegaan het binne 'n groter konteks van oorlogvoering, word die liriese subjek se selektiewe kyk na die foto vooropgestel deur twee inventarisse wat verskillende fokusse benoem. Hutcheon (1991:135) wys byvoorbeeld daarop dat 'n foto ook die aandag vestig op die waarnemende subjek. Die hoek van waaruit die kyker waarneem, word onder die soeklig geplaas. Waarom 
fokus die kommentator op bepaalde voorwerpe en wat is die funksie van dié vooropstelling?

Dit blyk dat die inventarisse bestaan uit twee reekse wat tiperende eienskappe van die Boerevegters op die foto benoem. Dit is gebaseer op fisiese en psigiese waarnemings. Deur 'n diachroniese afspeel van begrippe teen mekaar word die bedrieglikheid van voorkoms aan die kaak gestel. Die dubbele vergelyking in die twee middelste strofes sluit aan by kultuurhistoriese konsepte in die twee inventarisse. Daarmee word die rol van die sosiolek op die voorgrond geplaas. Albei die konsepte wat in die vergelykings gebruik word, naamlik "plaassondag" en "naweekvryers" is, eietyds gesien, anachronismes wat 'n bepaalde leefstyl tipeer. Dit prejudiseer die konsep "Boerevegters" in die titel van die gedig as 'n soortgelyke anachronisme.

Die vooropstelling van 'n kultureel-historiese afstand (en die gevolglike semantiese degenerasie), bring vanselfsprekend sosio-politieke afstand ter sprake. Hierdie verhulde diskoers is gemarkeer deur die trope (milde) ironie en parodie in die "Boerevegters"-gedig (vgl. byvoorbeeld strofe twee en drie en die laaste twee versreëls van strofe vier). Hierdie soort wending wat 'n digterlike diskoers kan neem, word deur Cloete in die eerste strofe van die vyfde afdeling van "oorloop" (Driepas, 1989:44) soos volg verwoord:

die kosbaarste poësie

- dit is ' $n$ ander haglike

soort oorloop - is vir die parodie

vatbaar en grens aan die belaglike

Meerduidige digterlike kommentaar dwing die foto as historiese representasie deurgaans uit fokus. 'n Teleskopering van sosio-historiese perspektiewe kom in sig. Dit kan vergelyk word met wat deur Hodge (1990:203) getipeer word as "anti-worlds and anti-meanings". Vir Hodge (1990:202) is die eietydse evaluering van die historiese 'n beslissende kriterium van betekenistoekenning in so 'n situasie. Die collage-tegniek wat in die gedig gesuggereer word, bly representasie maar terselfdertyd deurbreek dit die werklikheidspersepsie deur fragmentasie en diskontinuïteit (vgl. Hutcheon, 1991: 88). Dit gaan uiteindelik om 'n epistemologiese bevraagtekening van historiese kennis (Hutcheon, 1991:71). Die wetenskaplike neutraliteit van selfs die tegnologie (fotografie in dié geval) staan onder verdenking en bring volgens Davis (1977:62) mee dat "the photograph has ceased to be a window on the world, through which we see things as they are. It is rather a highly selective filter, placed there by a specific hand and 'mind'". 
Terwyl die foto 'n reële gebeurtenis ('n oorlog) vanuit 'n bepaalde sosiohistoriese perspektief daarstel, beoordeel 'n kyker-kommentator dit vanuit 'n ander sosio-historiese konteks. Hiervoor sou 'n denkbeeldige tydperk veronderstel kon word, byvoorbeeld 1989, die publikasiedatum van die bundel. Alhoewel aanvaar kan word dat sekere kodes van hierdie twee perspektiewe gedeel word (byvoorbeeld 'n Suid-Afrikaanse kultuurkonteks), aktiveer die verskille in tydruimtelike afstand die soort diskoers waartoe die twee slotreëls van die gedig aanleiding gee. Eienaarskap van dieselfde histories verowerde habitat vorm opnuut die basis van die eietydse konflik en betrek die vroeëre dispute. Die interpretasie van 'n kyker-leser in die gedig, eweneens met sekere gedeelde kulturele kodes, geskied teen die agtergrond van 'n volgende sosiohistoriese konteks, byvoorbeeld die jaar 1999 toe die honderdjarige herdenking van die Anglo-Boereoorlog plaasgevind het. Dit veronderstel 'n sosio-politieke opset wat eweneens verskil van die vorige perspektief. Hoorders wat sommige sosio-politieke kodes mag deel, maar ander nie, verteenwoordig die volgende representasie-interpretasiereaksie in die ketting. Aangesien die eersgenoemde twee gesigspunte (foto- en gedigperspektief) in opposisie was, kan aanvaar word dat elke verdere perspektief sal bydra tot 'n kompliserende diskoers oor sowel representasie as interpretasie. Wanneer die genoemde moontlike diskoerse in berekening gebring word, blyk dit dat die jukstaponering van foto- en kyker-kommentaar in die gedig perspektiefverruiming stimuleer ten opsigte van 'n spesifiek benoemde geval.

Die volgende vraagstellings word hierdeur op die voorgrond gestel: in watter mate kan 'n foto beskou word as 'n betroubare sosio-historiese dokument (vgl. die versreël: "dit ruik alles na lak en karton en papier.")? Op watter soort getuienis word gefokus? Wat was die doel daarmee? Watter lig werp dit op die konteks waaruit dit ontstaan het? Die geloofwaardigheid van die oorvertelling van gebeurtenisse uit die verlede in die hede word bevraagteken in historiografiese teorie sowel as in postmoderne fiksie. Insgelyks word verbandlegging tussen eietydse handelinge en 'n afwesige objek uit die verlede (vgl. Hutcheon, 1991:71) as problematies beskou.

\section{Leksikale inligting}

Aangesien 'n sosiale funksie van taal in die gedig op die spel kom, kan leksikale inligting 'n belangrike bydrae lewer tot die ontrafeling van die diskoers. Volgens Senekal (1986:115) moet in 'n vergelykbare ondersoek "elke diskursiewe struktuur as 'n besondere realisering van die sosiolek gesien word". Dit verskyn "as 'n gestruktureerde taaleenheid op die leksikale en diskursiewe (semantiese en sintaktiese) vlak". Dit is 
betekenisvol in dié verband dat hy ook aandui dat die sosiolek as groeptaal maklik aan die leksikale - die oppervlakkigste - dimensie herken word.

Die kwalifiserende begrip "Boere", koppel die tersaaklike vegters binne 'n Suid-Afrikaanse konteks aan 'n spesifieke historiese gebeurtenis, naamlik die Anglo-Boereoorlog van 1899-1902. Volgens HAT (1965:77) is 'n Boer onder andere spesifiek "'n lid van die Afrikanervolk". Die begrip boere verwys egter ook na landbouers of veeboere (HAT, 1965:77), wat impliseer dat dit grondgebruikers is. Hierdie betekenisnuanse reflekteer in die verwysing na "habitat" in die voorlaaste reël van die gedig. Boer is egter ook 'n begrip wat in die Suid-Afrikaanse konteks geringskattend gebruik word (soos blyk uit die afleiding "boeragtig"). Dit word byvoorbeeld gebruik om plattelander te kontrasteer met (gesofistikeerde) stedelinge of wêreldburgers (HAT, 1965:77). Dit funksioneer ook as pejoratiewe politieke tipering. "Boer" is dus 'n gelaaide sosio-politieke begrip.

Leksikale inligting aangaande die konsep habitat vervul 'n ewe belangrike funksie in die onderliggende diskoers aangaande oorlogvoering. Volgens HAT (1965:260) verwys habitat na die woongebied of verblyfplek van 'n bepaalde organisme - dier of plant. In Ilson (1, 1984: 752) word die volgende afleiding bygevoeg: "The place where a person or thing is most likely to be found". Habitat oefen invloed uit op die eiesoortige kenmerke van 'n spesie. Dit sluit aan by die leksikale inligting dat "Boere" kan verwys na grondeienaars wat landbou of veeteelt bedryf. Grondgebied word daarmee sentraal geplaas. Terwyl "Boere" semanties aansluit by "habitat", vorm "vegters" en "heldemoed" ook deel van 'n isotopie. Betekenisnuanses van laasgenoemde begrip - soos vreesloosheid, waagmoed, kordaatheid, parmantigheid, roekeloosheid en doodsveragting (De Stadler, 1994:338) - kom ter sprake. Ironiserende betekenisnuanses kom na vore deur begrippe wat windmakerigheid impliseer te jukstaponeer met die "heldemoed"-isotopie (byvoorbeeld in aansluiting by "veer in die paprand- en opslaanhoede").

Die oënskynlike naïwiteit van die vegters word ontmasker deur die ironie of sarkasme van die kyker-kommentaar in die versreëls: "die oorlogsdrag / van die menere / is soos dié van 'n plaassondag // of van outydse naweekvryers". Terwyl hulle poseer as figure wat hulleself laat geld (dit wil sê "menere" - vgl. HAT, 1965:537), weerspreek hulle ouderwetse en misleidende voorkoms die implikasies van hulle onderneming, naamlik die maak van oorlog as 'n "duvelrie". Die veelseggende verbinding van "gewere" en "menere" deur die rym beklemtoon hierdie ironiserende kommentaar. 


\section{Teksopbou}

Benewens die reeds genoemde polemiese opbou van perspektiewe, blyk dit dat daar ook ander spanningselemente in die gedig funksioneer. Die strofe-indeling en sinskonstruksie val nie saam nie. Strofes word aaneengeskakel deur enjambement. Dit dwing die leser om onderskeidend te lees.

Soos daar vier strofes is, kan vier sinsegmente onderskei word wat, interaktief met die strofebou, ook weer onderliggende patrone verraai. Dit vestig die leser se aandag op die semantiese spanningsverhoudinge of dissonante. Daar is sprake van 'n dubbelstruktuur wat 'n bydrae lewer tot betekenisontplooiing. Twee hoofsinne kan in die gedig onderskei word, alhoewel die begin van die tweede sin nie met 'n hoofletter aangedui word nie. Die werkwoorde is in elke geval in die teenwoordige tyd ("is" en "ruik"), wat veronderstel dat dit die agternaperspektief van die 'lesende' liriese subjek is. Dit word gejukstaponeer met die historiese handeling (verlede tyd) wat deur die foto opgeroep word. Die stylfigure (ironie en parodie) onthul die diskrepansie tussen die perspektief van die liriese subjek en die oorlogservaring van die historiese subjekte. Die opeenvolgende gebruik van twee verwante, maar tog verskillende trope, impliseer verdere betekenisnuanseringe.

Die eerste grammaties konvensionele sin skakel die twee middelste strofes deur middel van enjambement: "die oorlogsgedrag / van die menere / is soos dié van 'n plaassondag // of van outydse naweekvryers". Dit vorm, as middelpunt van die gedig, 'n brug tussen twee inventarisse waaraan vyf versreëls aan elke kant afgestaan word, dit wil sê indien die laaste twee reëls tot 'n nuwe segment gereken word. Die funksie van die vergelykings is ontveinsing of die onthulling van geveinsde onwetenheid, die etimologiese betekenis van die troop ironie (Gr. eironeia, kyk Van Gorp, 1986:201). Die afleiding wat hieruit gemaak kan word, is dat die voorkoms van die Boerevegters op die foto bedrieglik is (vergelyk die onderbeklemtoonde frase "dowwe Boere-oë vol grys woede"). Hierbenewens stel die kommentaar hulle voor as Don Quixote-agtige figure - dit wil sê hulle skep die indruk van dwase helde of alternatiewelik heldhaftige dwase.

Die tweede sin vorm oënskynlik 'n selfstandige eenheid, alhoewel dit deur die afwesigheid van hooflettergebruik weer in nouer verband staan met die voorafgaande sinsegmente. Dit word ondersteun deur die gebruik van die konjunktiewe anafoor "dit" in die laaste versreël, waardeur "die saak" beklemtoon word waarna dit terugverwys. "[D]ie saak van die habitat en heldemoed" is 'n eufemisme vir oorlog. Die pretensie is dat "die saak" verband hou met regspleging (dus geregtigheid) en dat dit 
oorlog ter wille van "die habitat" sanksioneer. Tradisioneel word heldemoed ter verdediging van eiendomsreg gereken as 'n eerbare en regverdigbare manlike reaksie op onreg. Hierdie siening word deur die relativerende slotreël as 'n futiele bedryf ontmasker.

Daar is reeds gewys op die semantiese verband tussen "Boerevegters" en die frase "habitat en heldemoed". Dit beteken dat die slotreëls ook soos volg gelees kan word: "Die saak van die (Foto) Boerevegters / dit ruik alles na lak en karton en papier". Deur dit wat in die res van die gedig gesuggereer is, kan hier tot dié slotsom gekom word: die "saak" van die "Foto Boerevegters" het algemene geldigheid vir poserende oorlogshelde.

Volgens leestekengebruik bestaan die gedig oënskynlik uit een sin wat begin met ' $n$ hoofletter en met neweskikkende sinne en bystellings deurloop oor vier strofes en eindig met 'n punt aan die einde van die gedig. Dit impliseer 'n samehangende en afgeronde semantiese inhoud. Die twee konvensionele sinne wat egter onderliggend onderskei kan word en opval op grond van die polemiserende stylfigure en die markering deur die kommapunt, word elk voorafgegaan deur 'n inventaris van voorwerpe (sien afdeling 8) waarin ooreenkomste en verskille voorkom. Sinclair (in Van Peer, 1988:264) omskryf so 'n inventaris ("list") as "a replacement of a syntagmatic choice by a paradigmatic one. The syntagmatic structure is not developed, but instead there is a reselection of the same element of structure". Die inventarisse dwing dus 'n alternatiewe leesproses af.

'n Vergelyking tussen die twee inventarisse openbaar 'n opmerklike simmetriese opbou - tien items word genoem voor elke neweskikkende sin. Dié inventarisse skep die indruk van outentisiteit ondanks die ander ambivalente elemente. Benoeming stel referensiële taalgebruik voorop.

Die sosiokode in die gedig lewer 'n belangrike bydrae tot die betekenisontplooiing. Kleredrag is by uitstek 'n kultuurmerker en periodiseerder. Kulturele gebruike is ' $n$ ewe betekenisvolle merker. Verskillende afleidings kan gemaak word uit 'n vergelykende ondersoek na die voorwerpe in die onderskeie reekse. Alhoewel daar nie 'n volledige parallellisme is tussen die twee inventarisse nie, is daar voldoende ooreenkomste om tot die gevolgtrekking te kom dat die primêre funksie van die verwysings kultuur-histories van aard is (vgl. Sinclair in Van Peer, 1988:270). By nadere ondersoek blyk dit egter dat dit ook funksioneer as die waarnemer in die gedig se kommentaar op die onderliggende tema 
van oorlog. Die twee inventarisse se verskil in samestelling is semanties relevant.

Verwysings na "baard" kom drie maal voor in die eerste reeks. Dit is 'n merker van manlikheid, soos ook blyk uit die aanvanklike onderskeiding van "melkdons" (infantiele baard) en "weglêmoestas" (simbool van hipermanlikheid - vgl. Herder, 1986:20). Laasgenoemde differensiëring kan ook die handhawing van 'n patriargale verhouding vooropstel. So 'n verhouding word selfs sterker gesuggereer deur die paar "penkoppe en korrelkopooms" in die tweede inventaris. Die kontrastering van "papranden opslaanhoede" onderskeidelik, sluit by hierdie proses van onderlinge sosiale hiërargisering aan. Hierbenewens is daar sprake van 'n derde kategorie deelnemers, naamlik "nederige lojale agterryers". Laasgenoemde is 'n frase wat sosio-politieke afstand tussen historiese teks en kyker-perspektief ter sprake bring. In die eietydse politieke konteks is dit 'n polemiserende tipering. Daarom kan die frase (ook) as ironiserende kommentaar van die liriese subjek gelees word. Binne die primêre historiese konteks, dié van die Boerevegters, dra dié tipering ("nederige lojale agterryers") 'n positiewe lading. Hierdie moontlikheid word in die gedig verreken deur die plasing van dié kategorie in strofe drie. Hulle vorm deel van die eie groep ("die pure penkoppe en ou korrelkopooms") wat stelling inneem teenoor die vyand.

'n Opvallende kenmerk van die twee reekse is die ironiese interaksie tussen oënskynlik passiewe en aggressiewe elemente en die herhaling van sekere konsepte, naamlik baard, hoede en wapens. Albei inventarisse begin met die benoeming van kultuurhistoriese voorwerpe wat netsowel deel kan wees van 'n alledaagse lewenspatroon. Die vyfde verwysing van die eerste inventaris, naamlik "dowwe Boere-oë", markeer 'n ambivalensie. Wat aanvanklik "dowwe ... oë" was, word gekontrasteer met die frase "vol grys woede". Die eerste voorwerp wat hierna volg in die reeks, naamlik "gepoleerde kamaste", verkry 'n militêre konnotasie aangesien dit opgevolg word met "koeëltas / om die skouers". Hierop word twee maal na wapens verwys. Dit is veelseggend dat "baard" en "verkyker" in plaas van "oë" - laasgenoemde suggereer sowel verskanste as bewapende oë - deel vorm van hierdie reeks. "Weglêmoestas" en "koeëltas" (wapentuig) is reeds antisiperend deur die rym verbind in strofe een (vgl. ook die klankmatige verbinding van "menere" en "gewere"). Die wysiging van "melkdons en weglêmoestas" na "baard" in dié geval - dit wil sê ongekwalifiseerd manlik - sluit hierby aan. In Cloete se gedig "geelperdridder" (1998:26), met eweneens oorlog as 'n tema, word naamlik beweer: "van oudsher had baarde / selfs vir die pouse militêre waarde". Die laaste vyf voorwerpe van die eerste inventaris word onomwonde as "oorlogsdrag" bestempel in strofe twee. Die element van 
aggressiwiteit word egter onmiddellik deur die rym van "oorlogsdrag" en "plaassondag" gerelativeer. Uit albei die inventarisse blyk die emosionele ondertoon wat deur herhaling en kontras versterk word.

Die eerste twee items in die tweede reeks, naamlik "penkoppe en korrelkopooms", sluit op simboliese vlak aan by "hoede", wat in die eerste reeks eweneens in die eerste en tweede posisie staan. Herder (1986:96) verduidelik die verband tussen hoed en kop soos volg: "(Hat) sometimes symbolizes the head or the thoughts; changing hats may also signify changing one's views or opinions, or one's occupation or role". Die gewysigde "vilthoed" in die agtste posisie van die tweede reeks dui op die laasgenoemde moontlikheid. Die kontras tussen strofe drie en vier is ooglopend. Eersgenoemde strofe bevat weer eens begrippe wat niks meer as kultuurhistoriese merkers hoef te wees nie terwyl wapentuig (drie items) in strofe vier gekonsentreer word, gekoppel met "vilthoed". In die lig daarvan dat die Boerevegters se behendigheid te perd 'n belangrike deel uitgemaak het van hulle oorlogsmaneuvers, is dit betekenisvol dat hierdie isotopie verteenwoordig word deur drie items in die tweede inventaris ("perde en saals en tooms") teenoor een so 'n verwysing in die eerste inventaris ("kamas"). Twee sleutelbegrippe wat in die gedig vooropgestel word, is koppe/hoede en wapens. Selfs die verwysings na "oë" en "baard" verraai onderliggende motiewe wat hiermee verband hou. Die afleiding kan gemaak word dat die implikasie hiervan is dat koppe wapens beheer. Indien betekenisnuanses soos infantiliteit en onnadenkendheid as implikasies van onderskeidelik "penkoppe" en "korrelkopooms" (vgl. De Stadler, 1994) in aanmerking geneem word, blyk die ironiese intensie van die bepaalde vooropstelling van die genoemde begrippe.

Die oorgang van passiwiteit na aggressiwiteit word in die laaste twee reëls van die slotstrofe geïroniseer deur "bandelier"' (wapentuig) en "papier" (teenstellend power en verganklik) deur die eindrym van versreëls twee en vier te verbind. Dit is veelseggend dat "papier" die (simboliese) laaste woord is in 'n gedig met oorlog as tema! Die implikasie is dat oorlog en alles wat daarmee saamhang, histories gesproke, degradeer tot papier - dit wil sê argiefstukke. Die foto van Boerevegters funksioneer as 'n sprekende voorbeeld hiervan. Elke agternaperspektief op 'n oorlog word 'n terugverwysing na brokstukke "papier" wat legkaartgewys gerekonstrueer word (vgl. die slotreël: "Dit ruik alles na lak en karton en papier). In die gedig "Allofonie" (Cloete, 1985:94) is onder andere beweer: "Deels is die geskiedenis / my eie oog, deels is dit kollektief." 
8. Die gedig en die inventarisse

\section{"Foto Boerevegters"}

(T.T. Cloete. Driepas, 1989:111)

1 Veer in die paprand- en opslaanhoede,

inventaris 1 melkdons en weglêmoestas, dowwe Boere-oë vol grys woede, gepoleerde kamas en koeëltas

2 om die skouers baard, gewere, verkyker, die oorlogsdrag $\sin 1$ van die menere is soos dié van 'n plaassondag

3 of van outydse naweekvryers;

pure penkoppe, ou korrelkopooms, inventaris 2 nederige lojale agterryers, perde en saals en tooms

$4 \quad$ kruithorings, vilthoed geweerloop, bandelier, die saak van die habitat en heldemoed dit ruik alles na lak en karton en papier.

$\sin 2$

(swartdruk ter wille van onderskeiding - RR)

\section{Inventarisse}

Nommer 1

1 koppe (paprandhoede)

2 koppe (opslaanhoede)

3 baard (melkdons)

4 baard (weglêmoestas)

5 оё

6 berede toerusting (kamas)

7 wapentuig (koeëltas)

8 baard

9 wapentuig (gewere)

10 oё (verkyker)
Nommer 2

1 (pen)koppe

2 (korrel)kop(e)(ooms)

3 agterryers

4 berede toerusting (perde)

5 berede toerusting (saals)

6 berede toerusting (tooms)

7 wapentuig (kruithorings)

8 koppe (vilt)hoed

9 wapentuig (geweerloop)

10 wapentuig (bandelier) 


\section{Waarheid en leuen as perspektiefwisseling}

Uit sowel sy prosa as sy poësie blyk dit dat Cloete die digterlike spel met die woord tipeer as 'n kulspel met waarheid en leuen. Die titel van sy prosadebuut, Die waarheid gelieg (Cloete, 1984), is onder andere 'n insiggewende subteks vir sy poësie. In die slotstrofe van die gedig "maar ...111", word tot die volgende gevolgtrekking gekom (Cloete, 1986:46):

die oog

wat uitsoek

hy maak onvermydelik droog

in sy ewige hoek

Die spel met perspektiefwisseling lei in die "Boerevegters"-gedig tot 'n vorm van "taalskadeloosstelling". Elke element van die gedig dra aktief by tot die digterlike diskoers wat historiese sowel as eietydse persepsies oor oorlog relativeer. Waarheid en leuen word spelenderwys afgespeel teen mekaar. Hierdie digterlike procédé is 'n belangrike sleutel tot 'n verstaan van Cloete se digterlike oeuvre.

\section{Gevolgtrekking}

Deklaratiewe of retoriese stylfigure vorm nie deel van die tegniek van "taalskadeloosstelling" nie. Daar word by voorkeur gebruik gemaak van trope wat onderbeklemtoning (understatement) en ambivalensie vooropstel. "Taalskadeloosstelling" funksioneer paradoksaal as 'n vorm van betekenisontploffing omdat dit meerduidigheid bevorder. $\mathrm{Na}$ aanleiding van Cloete se "Boerevegters"-gedig kan die sosiale funksie van die digter getipeer word as die vermoë om perspektiefverruiming te bevorder deur middel van die digterlike spel met woorde.

\section{Bibliografie}

Cirlot, J.E. 1982 (1962). A dictionary of symbols. London : Routledge \& Kegan Paul. Cloete, T.T. 1974. Die korrektiewe gegewe. In: Woord en wederwoord. Kaapstad : Human \& Rousseau. p. 30-43.

Cloete, T.T. 1982. Jukstaposisie. Kaapstad : Tafelberg.

Cloete, T.T. 1984. Die waarheid gelieg. Kaapstad : Tafelberg.

Cloete, T.T. 1985. Allotroop. Kaapstad : Tafelberg.

Cloete, T.T. 1986. Idiolek. Kaapstad : Tafelberg.

Cloete, T.T. 1989. Driepas. Kaapstad : Tafelberg.

Cloete, T.T. 1998. Uit die hoek van my oog. Kaapstad : Tafelberg.

Davis, Douglas. 1977. Artculture: essays on the post-modern. New York : Harper \& Row.

De Beaugrande, Robert. 1980. Text, discourse and process. Toward a multidisciplinary science of texts. Norwood : Ablex.

De Beaugrande, Robert-Alain \& Dressler, Wolfgang Ulrich. 1981 (1972). Introduction to text linguistics. London : Longman. 
Derrida, Jacques. 1991. A Derrida reader. Edited by Peggy Kamuf. New York : Columbia.

De Stadler, L.G. 1994. Groot tesourus van Afrikaans. Halfweghuis : Southern boekuitgewers.

Easthope, Antony. 1983. Poetry as discourse. London : Methuen.

Grote Winkler Prins encyclopedie. 8ste druk. Band 7. 1980. Amsterdam : Elsevier.

HAT. Handwoordeboek van die Afrikaanse taal. 1965. Johannesburg : Voortrekkepers.

Herder. 1986 (1978). The Herder dictionary of symbols. Wilmette : Chiron Publications.

Hodge, Robert. 1990. Literature as discourse. Cambridge : Polity Press.

Hutcheon, Linda. 1991 (1989). The politics of postmodernism. London : Routledge.

Ilson, Robert. Consultant editor. 1984. Reader's Digest great illustrated dictionary. London : Reader's Digest.

Knuvelder, G.P.M. 1970. Handboek tot de geschiedenis der Nederlandse letterkunde. Deel 1. 5de druk. s'Hertogenbosch : Malmberg.

Lakoff, George. 1980. Metaphors we live by. Chicago : University of Chicago press.

Koopmans, J. (red.) 1917. Mariken van Nieumeghen. Groningen : Wolters.

Pretorius, Fransjohan. 1998 (1985). Die Anglo-Boereoorlog 1899-1902. Kaapstad: Struik.

Senekal, Jan. 1986. Teks leser konteks. Johannesburg : Perskor.

Snyman, Henning. 1983. Mirakel en muse. Johannesburg : Perskor.

Stutterheim, C.F.P. 1963. Conflicten en grenzen. Amsterdam : Polak \& Van Gennep.

Uspensky, B. 1983 (1973). A poetics of composition. Berkeley : University of California Press.

Van Gorp, H. e.a. 1986. Lexicon van literaire termen. Groningen : Wolters-Noordhoff.

Van Peer, Willie 1986. Stylistics and psychology. Investigations of foregrounding. London : Croom Helm.

Van Peer, Willie (ed.) 1988. The taming of the text: explorations in language, literature and culture. London : Routledge.

\section{Kernbegrippe:}

digterlike diskoers

gesigspunt

representasie en interpretasie

taalskadeloosstelling

vooropstelling

\section{Key concepts:}

disempowerment of speech

foregrounding

poetic discourse

point of view

representation and interpretation 